\title{
Religion and Development: A Practitioner's Perspective on Instrumentalisation
}

\author{
Cassandra Balchin
}

Abstract Some international development agencies from Europe and North America, as well as some multilateral agencies, have played a critical role in instrumentalising religion in their development policy and practice. This article, written from the perspective of an activist-scholar, reflects on how religion has featured in these donor policies and the implications for advancing rights-based gender agendas in various contexts. It argues that development policy towards religion takes three broad approaches which are neither mutually exclusive nor do they unfold in a particular linear path. These approaches are to see religion as the main developmental obstacle, the only developmental issue to the exclusion of all others, and the primary solution to developmental problems. All three approaches are problematised in this article and are bound by their essentialisation of 'Muslim women' as a homogeneous group, as if bound by a common identity and a common set of needs.

\begin{abstract}
1 Introduction
The whole notion of 'instrumentalisation' can lead one into very dangerous waters - especially in connection with something as essentially intangible as religious belief. It comes down to a question of sincerity of intent, or what Muslims might call neeyat - a concept (ironically) loaded with religious significance. One cannot actually know the intention of a donor, policymaker, a religious fundamentalist or a rights activist, when they support the use of a religious argument in advancing their goals; indeed it would be presumptuous and discriminatory to make any assertion about an individual's intent.

But what is feasible, which this article aims to show, is focusing on religion in current development policy by international development agencies from Europe and North America, as well as some multilateral agencies. And from the impact of this policy, one can trace backwards in order to comment on the presumed institutional and collective agendas that inform various approaches to religion in development policy. The analysis presented here was something I developed in the early 2000s (Balchin 2003), and is, sadly, still applicable. It
\end{abstract}

illustrated that when approaching the question of religion, development policy takes one of three broad perspectives: to see religion as the main developmental obstacle; the only developmental issue to the exclusion of all others, and the primary solution to developmental problems. They are not mutually exclusive, in that any single development agency may employ all three at the same time.

This analysis emerged from personal experience in development, and specifically women's rights work in Muslim contexts. I worked for several years with Shirkat Gah women's resource centre (SG) in Pakistan, one of the country's foremost women's rights organisations, and then at the coordination office of the international solidarity network, Women Living Under Muslim Laws (WLUML). ${ }^{2}$ This work has continued as, while retaining links with Pakistan and WLUML, I am now part of Musawah, ${ }^{3}$ a global initiative for equality and justice in the Muslim family, and a founder of the Muslim Women's Network-UK. ${ }^{4}$

This has given me hands-on experience of how policymakers and donors, multilateral and bilateral and INGOs, as well as how governments

IDS Bulletin Volume 42 Number 1 January 2011 (c) 2011 The Author. IDS Bulletin (? 2011 Institute of Development Studies Published by Blackwell Publishing Ltd, 9600 Garsington Road, Oxford OX4 2DQ, UK and 350 Main Street, Malden, MA 02148, USA 
frame the whole question of the category 'Muslim Women' and how they problematise religion and development. Other research has reinforced this experience.

\subsection{A new policy direction}

Before continuing with the analysis, I would like to comment on the notion that the instrumentalisation of religion in development policy represents a new policy direction, perhaps associated with $9 / 11$. One can trace the "problem of Islam's back to globally significant political developments in Afghanistan and Iran in the 1970 s, and beyond. Certainly by the early 1990s, conferences started being held about women, religion and development (especially in the Netherlands and the Scandinavian countries): they were very specifically focused on women and Islam. There were no conferences on women and Catholicism and development, or on Judaism, development and women. This trend has continued - and with greater vigour in the post9/11 context, where the radicalisation of Muslim societies has become more evident side-by-side with the pursuit of the 'war on terror', and Bush's gag rule affected the US development policy and the work of, for example UNIFEM, UNFPA and the whole UN process. Moreover, development charities influenced by fundamentalist Catholic agendas, such as World Vision, have impacted on HIV and AIDS work in Africa. The impact has been to shift global development policy to the right. Development policy was at the time of Bush increasingly influenced by Christian right-wing agendas.

Yet, despite the apparent concern about women in Muslim contexts, the very essentialised approach that characterises some development approaches to women, religion and development - which includes what we can call the instrumentalisation of religion - have not changed since the early 2000 s.

\section{Religion as the main developmental obstacle}

Of the three approaches, the first is to see religion as the developmental obstacle; the presumption is that: 'If only these people would get rid of their religion, then development will happen'. Such an approach ignores global and local structural inequalities that contribute to underdevelopment and poverty. Moreover, religious identification is understood as a sign of backwardness, something not 'modern' and thus out of tune with the progress of development. This is applied almost exclusively to Muslim societies. Such an approach often characterises all men as rights violators and women as passive victims, which fails to interrogate political and ideological differences and active identity choices by both women and men. Yet research by AWID (Association of Women's Rights in Development) has revealed how in the experience of women's rights activists, religious identification can be part of the very modern phenomenon of religious fundamentalisms, and that there are women who actively support such agendas (Balchin 2008). At the same time, Musawah and other rights-based initiatives in Muslim contexts (as well as rightsbased movements in other religious contexts) also demonstrate how there is nothing intrinsically anti-human rights about religion.

\section{The only developmental issue to the exclusion of all others}

The second approach sees religion as the only developmental issue to the exclusion of all others. It was clearly visible in development policy by the mid-1990s and is likely an outcome of the then contemporary global resurgence of identity politics and essentialisation of communities. This ignores the impact of structural factors such as class, as well as the impact of life cycle stage, ethnicity, etc. on developmental opportunities. Above all, it homogenises the category 'Muslim women'. As I have written elsewhere on the problem of labelling (Balchin 2007), consider Muslim women in Britain: a Scottish white convert, a Somali refugee and a third generation woman of Pakistani origin. How much do they have in common in terms of developmental needs? And this is just within one country; is the developmental notion 'the problems of Muslim women' meaningful at all? Such an approach leads to the production of research and analysis, such as: 'In many Muslim cultures, motherhood constitutes a dominant part of Muslim concepts of female identity' (Netherlands Special Programme 1993: 21). In how many societies does this not apply - whether supposedly developed or underdeveloped and no matter what the local religious belief or non-belief? What is the point in making that assertion about Muslims - does it help development analysis and policymaking? These are reports and conferences that have been funded with tax payers' money and development aid that multiplies the debt burden of generations of inhabitants of the global South. To what end? 
Seeing religion as the developmental issue, means that donor policy will necessarily privilege those who are in representative authority and then the search is on for religious leaders that can be engaged in development - even if religious leaders have to date, in a given context, played a largely negative role in advancing rights or even if on the ground religious authorities are actually not the main decision-makers on a particular developmental issue. I recall the fury of a women's rights activist from the Mindanao region in the Philippines in the 1990s. A foreign bilateral agency had apparently gathered local $u l e m a^{6}$ in order to produce a statement supporting women's reproductive rights from an Islamic perspective. Although this was not a normal sphere of the local ulema's concern, the statement was duly issued, but more importantly, the gathering facilitated networking among the ulema that subsequently contributed to the formation of a political grouping that promoted a fundamentalist vision of Islam. In other words, a development approach reinforced conservative interpretations of religion and strengthened the power of those who do not have pluralism and equality at heart.

Above all, this rush to 'find the religious' is rarely backed by sophisticated knowledge of the diversities among religious groups. Many mainstream development and human rights organisations that have for decades identified themselves as 'secular' have tended to ignore the role of religion in society. Now having suddenly discovered it, they lack the analytical tools essential for an informed engagement that can sufficiently account for the diversities of political positions among religious groups and religious authorities. It is fascinating that the few mainstream development and human rights organisations that are currently consciously attempting to address this lack of capacity are sometimes wary of making their effort publicly visible. Their concern appears to be a fear of being labelled as 'soft on fundamentalism' or, more commonly, a fear of being seen to be judging religion. In both instances, this fear is founded on a conflation of religion and religious organisations; while the former cannot be judged in any empirical manner, the role of religious organisations and their agendas in advancing or obstructing rights can and should be judged.

Finally, approaches that privilege religion as the developmental issue accord with the Muslim fundamentalist assertion that Islam and Muslims deserve 'special' treatment. In a perverse distortion of the notion of 'cultural sensitivity', the 'special treatment' approach demands respect for cultural relativist assertions, for example of how maternal health programmes are 'inappropriate' for Yemeni rural communities. ${ }^{7}$ Another example was a DFID-funded research report looking at how Sharia ${ }^{8}$ might be used to advance women's rights in northern Nigeria (DFID et al. 2006). This DFID sponsored report's recommendations did not match the Nigerian constitution, and its highly conservative content was far less progressive than the analysis of local women's rights activists, including those who worked within a religious framework. Thus, local law and the local women's movement were brushed aside.

\section{The primary solution to developmental problems}

This brings us to the third approach - that of seeing religion as the primary developmental solution. I regard this as analytically and historically a non-identical twin of the second approach, although research needs to be done to establish more clearly the contextual factors which led to its appearance. This approach presumes that development, which can be a bitter pill, will be 'swallowed' as long as it is wrapped in the sugar coating of religion. The parallels between donor policies and the Muslim fundamentalist mantra 'Islam is the solution', is not lost on rights activists from Muslim contexts. In both, the outcome is an instrumentalisation of religion accompanied by what, I argue, is a negative impact on development and women's rights. By privileging religion, development policy of this type ignores rights struggles that are not framed with reference to religion including rights demands that are based on concepts of citizenship. And yet Muslim societies are invariably charged with being 'failed states'. How far has donor policy contributed to strengthening a shared notion of citizenship in Muslim majority countries?

Such development policy also reinforces the false dichotomisation of secular and religious approaches to development; yet in my experience on the ground, rights work is far less binary. For instance, Shirkat Gah's paralegal training for community activists focused largely on the constitution, state law and customary practices. But since Islam and Muslim laws are 
one of the sources of law in these spheres, challenging the official conservative interpretation of Muslim laws was inevitable, including highlighting the possibility of rightsbased interpretations or at least interpretive diversity in Muslim history. Another example is SG's legal awareness trainings which made marginalised women aware of their right to mahr (an obligatory payment by a husband to the wife under Muslim family laws). This right was highlighted not so much as a religious duty, although it is derived from religious laws, but simply as a right under legislated family laws: thus, the lines between 'civil' and 'religious' laws or 'secular' and 'religious' approaches are by no means clear-cut. Moreover, where rights work is more polarised, these donor policies can undermine - through who and what is funded efforts by local rights activists to build alliances between secular and religious frameworks and groups. Take a hypothetical example: in India, the relationship and alliances between those feminist activists in Muslim communities who work from within a religious framework and those who prioritise secular approaches is fragile and constantly debated; rights movements specifically focusing on Muslim women are still nascent. Imagine the potential for derailing local organic processes if foreign development aid were easily available only to those working from within a religious framework.

The approach of seeing religion as the developmental solution is found not just in the sphere of poverty and development - it is also visible, albeit in a slightly different form, in justice sector reform. Here, the current fashion among some international financial institutions (IFIs) and some multilateral and bilateral agencies, is increasingly to assert that non-state legal systems based on culture and religion are a solution to the poor's lack of access to justice due to the inadequacies of the formal justice sector. While an understanding of legal pluralism is absolutely vital and welcome, the privileging of non-state and 'from within' approaches to justice sector reform has very serious implications for the human rights of marginalised sectors of society, notably women, as outlined in ICHRP (2009).

Privileging the role of religious organisations in service-delivery - whether of justice or development sectors such as health and education - constitutes the instrumentalisation of religion because, quite apart from its impact on rights struggles, it undoubtedly serves a neoliberal privatisation agenda. For instance, extra-judicial arbitration of family matters under Alternative Dispute Resolution (ADR) legislation reduces the case load burden on the formal legal system, leaving it for more 'serious' matters, such as commercial disputes. To justify this privatisation of law, policymakers will argue that such ADR accords more closely with people's cultural and religious aspirations. This approach is visible in a diversity of contexts, including for example Brazil, Britain and India. The way a great many ADR systems have worked to date may well be more in tune with hegemonic local cultural and religious norms than the formal legal system, but they have far less often been in tune with the poor's aspirations for justice and women's aspirations for equality. ${ }^{9}$ AWID's research has also found that the privatisation of the delivery of basic services, has undoubtedly served to strengthen the legitimacy of conservative and fundamentalist religious groups who have often been the only force with sufficient resources and infrastructure to pick up the slack in service delivery. This is happening not just across developing countries but also in servicedelivery for minorities in developed countries. According to Pragna Patel, of the women's group Southall Black Sisters, which primarily works with Asian women in the United Kingdom:

The privatization agenda is giving religion a space because the state then wants to offload its functions onto religious institutions. Who has the capacity and resources? Religious institutions! When we have women who have no recourse to public funds, who is it who can give them shelter and food? The gurdwara [Sikh temple]! ... This is problematic for women. (Balchin 2010)

Those who see religion, and specifically Islam, as a developmental obstacle throw the net too wide; they blame all they identify as Muslims for their own fate and fail to see the internal contestation over rights and responsibilities that has been a feature of Islam since its emergence. ${ }^{10}$ At the same time, this focus on Islam ignores the negative impact on development of religious fundamentalisms in other contexts. AWID's research $^{11}$ found that in the experience of women's rights activists affected by all the world's religions, major and minor and across 
regions, religious fundamentalisms are bad for development. For instance, the 1,600 women's rights activists who responded to AWID's online survey highlighted the negative impact of religious fundamentalisms on a whole range of rights that are broadly seen as part of a rightsbased development agenda: sexual and reproductive health and rights, freedom from violence against women, women's political and economic participation, and equality in family laws - all this, quite apart from their impact on democracy and pluralism overall. Meanwhile, those who privilege religion as a developmental solution also tend only to regard as legitimate interlocutors those who visibly claim a Muslim identity. In the case of Muslim women, this is often stereotyped as those who veil and who hold conservative positions about the status of women in society. Thus, in certain instances, the labelling inherent in these developmental approaches fails to cast the net widely enough.

\section{Conclusion}

The points above indicate the profound challenges that labels present us in development practice and rights work today. AWID's research in the context of feminist strategies of resistance to religious fundamentalisms notes that: 'The complexities and constant shifts that are characteristic of the current historical moment mean that the old categories and existing terminologies are inadequate for capturing this reality and do not help feminists convey what is happening on the ground' ${ }^{12}$ It is clear that, overall, social movements, including development actors, are behind in addressing the challenges of labelling.

The inadequacies of some current donor approaches to religion and development, and specifically approaches to women's development in Muslim communities, is in stark contrast to the creative and binary-challenging initiatives that some women's rights activists have for decades been using on the ground. Many local human rights and women's rights groups, whether in the area of access to justice or development more broadly, have engaged with religion and development in contextually-specific ways that advance rights. A more recent example is Musawah, a global initiative for equality and justice in the Muslim family, launched in February 2009. While it identifies itself as led by Muslim women, using rights-based interpretations of religion is just one of four approaches in its analytical framework. In its demand for equality, the Musawah framework ${ }^{13}$ takes a holistic approach emphasising Islamic principles, the human rights framework, constitutional guarantees of equality and nondiscrimination, and lived realities. The extent to which each of these four approaches is emphasised is up to the individual activists and organisations linked through Musawah. As a movement that is still very much in the process of constructing and identifying itself, Musawah, and the intense discussions which have been part of the development of its analytical framework, messaging and relationships with other women's movements, will make for a fascinating case study of the role of religion in women's development.

There is a need to engage with women's rights activists to document their experiences of successful engagement with religion to advance rights in their particular contexts. There is a broad range of this engagement - from actively confronting religious fundamentalists to supporting rights-based interpretations of religion to emphasising shared national citizenship and protecting secular spaces. There also needs to be independent documenting of the situations where, according to the anecdotal accounts of some local women's rights activists, donor instrumentalisation of religion actually harmed women's rights such as in Afghanistan and Sudan. It may be difficult for local women's groups to document these cases because of their continuing dependence upon the very donors whose policies have at times undermined their rights work. What is important, however, is that wherever successful strategies do emerge, these are not simply picked up as quick fixes that are presumed to apply as a model in all contexts. In the case of strategies that use a religious framework, the decontextualised application of 'from within' approaches can be a slippery slope towards the instrumentalisation of religion. 


\section{Notes}

1 For further information on the Shirkat Gah women's resource centre, see www.shirkatgah.org

2 For further information on the coordination office of the international solidarity network, Women Living Under Muslim Laws, see www.wluml.org

3 For details of Musawah, a global initiative for equality and justice in the Muslim family, see www.musawah.org

4 For further information on the Muslim Women's Network-UK, see www.mwnuk.co.uk

5 In development policy, this invariably translates into the 'problem of Muslim women', an essentially colonial practice of instrumentalising women's status.

6 Community religious leaders.

7 An international development agency staffer who was confidently familiar with local power dynamics and how culture can be used to obstruct or advance rights, recently recounted how she overrode such concerns and went on to establish a highly popular local maternal health programme. But not all development actors have the required capacity to deal with such situations.

8 Religious Law.

9 ICHRP 2009 includes examples of the negative rights impacts of ADR from Brazil, Canada, India and Pakistan. Even one of the

\section{References}

Balchin, Cassandra (2010) Towards a Future without Fundamentalisms Analyzing Religious Fundamentalist Strategies and Feminist Responses, Toronto: AWID, forthcoming

Balchin, Cassandra (2008) Religious Fundamentalisms Exposed: Ten Myths about Religious Fundamentalisms, Toronto: AWID

Balchin, Cassandra (2007) "Muslim Women" and "Moderate Muslims": British Policy and the Strengthening of Religious Absolutist Control over Gender Development', in Joy Moncrieffe and Rosalind Eyben (eds), The Power of Labelling: How People are Categorised and Why it Matters, London: Earthscan

Balchin, Cassandra (2003) 'With Her Feet on the Ground: Women, Religion and Development in Muslim Communities', Development 46.4: 39-49 current foremost champions of ADR, the World Bank in its online Access to Justice Topic Brief notes that ' $[. .$.$] both the efficiency$ and justice of various ADR schemes have been questioned. For example, it is argued that ADR based on traditional social relationships may reduce women's access to justice when prevailing norms discriminate against women'. http://web.worldbank.org/WBSITE/ EXTERNAL/TOPICS/EXTLAWJUSTINST/0, ,contentMDK:20756347 isGURL:Y menuP K:1990386 pagePK:210058 piPK:210062 t heSitePK: 1974062,00.html

10 For further information, see www.musawah.org/ docs/pubs/wanted/Wanted-MKM-Summary.pdf

11 For details on AWID's research, see www.awid.org/eng/About-AWID/AWIDInitiatives/Resisting-and-ChallengingReligious-Fundamentalisms/What-s-newfrom-this-initiative/New-Insights-onReligious-Fundamentalisms-ResearchHighlights

12 For further information, see www.awid.org/eng/About-AWID/AWIDInitiatives/Resisting-and-ChallengingReligious-Fundamentalisms/What-s-newfrom-this-initiative/New-Insights-onReligious-Fundamentalisms-ResearchHighlights, p. 114

13 For details, see www.musawah.org/ framework_action.asp

DFID, British Council, Ahmadu Bello University (2006) Promoting Women's Rights through Sharia in Northern Nigeria, www.ungei.org/resources/ 1612_800.html (accessed 19 November 2010)

ICHRP (2009) When Legal Worlds Overlap: Human Rights, State and Non-State Law, Geneva: ICHRP

Netherlands Special Programme (1993) Study prepared by the Centre for Women's Studies at the University of Nijmegen on behalf of the Netherlands Special Programme on Women and Development for the seminar, 'Women, Islam and Development', organised by the Netherlands Ministry of Foreign Affairs, unpublished conference paper, The Hague, 15 September 